DOI: 10.1515/ausp-2016-0003

\title{
The Story of Orpheus and Eurydice in Coetzee and Rilke
}

\author{
Ottilia VERES \\ Partium Christian University (Oradea, Romania) \\ Department of English Language and Literature \\ veresottilia@gmail.com
}

\begin{abstract}
J. M. Coetzee's The Master of Petersburg (1994) is a text about a father (Dostoevsky) mourning the death of his son. I am interested in the presence and meaning of the myth of Orpheus and Eurydice in the novel, compared to the meaning of the myth in R. M. Rilke's poem "Orpheus. Eurydice. Hermes." (1904). I read the unaccomplished encounter between Orpheus and Eurydice as a story that portrays the failed intersubjectity plot of Coetzee's novel(s). Following Blanchot's reading of the myth, I examine the contrasting Orphean and Eurydicean conducts - Orpheus desiring but, at the same time, destroying the other and Eurydice declining the other's approach. I argue that Orpheus's and Eurydice's contrasting behaviours can be looked at as manifestations of a failure of love, one for its violence, the other for its neglect, and thus the presence of the myth in The Master of Petersburg is meaningful in what it says about the theme of intersubjectivity in Coetzee's oeuvre.
\end{abstract}

Keywords: Orpheus, Eurydice, encounter, intersubjectivity.

J. M. Coetzee's seventh novel, The Master of Petersburg (1994), is a novel about the trauma of losing a son; it is a mourning text both in the sense that in it the protagonist Dostoevsky tries to work through the trauma of loss (and through him Coetzee tries to work through the trauma of the loss of his own son ${ }^{1}$ ) and in the sense that the novel textually performs the work of mourning by trying and failing - to understand this loss. Dostoevsky cites the story of Orpheus and Eurydice in reference to the death of his son and to his experience of this loss. The presence or invocation of the Orpheus myth in The Master of Petersburg is significant for my argument in that it tells the story of a wished-for but (never realized) failed encounter and in this it is suggestive of the difficult and wounded

1 Mourning as a theme of the novel has a biographical aspect as Coetzee's son died in 1993 in an accident (in a mysterious fall from a high balcony), when he was twenty-three, shortly before the writing of The Master of Petersburg. 
nature of intersubjectivity that Coetzee's novels evoke through their engagement with the theme of the encounter with another human being.

In The Master of Petersburg Dostoevsky's mourning is gradually saturated with certain mythological motifs and stories. It is as if the very state of mourning evoked mythological stories by its sheer archaic intensity. Reminiscences and traces of the myths of Daedalus, Penelope, and Orpheus are at play in the novel, informing Dostoevsky's mourning and his "tale of Pavel," his son. These stories play a crucial role, as the fictional Dostoevsky remarks: "One by one, in fact, the old stories are coming back, stories he heard from his grandmother and did not know the meaning of, but stored up unwittingly like bones for the future. A great ossuary of stories from before history began, built up and tended by the people" (Coetzee 2004a, 126; emphasis mine).

Tamás Valastyán discusses the Orpheus-Eurydice encounter as an allegory of the act of interpretation in which Orpheus plays the role of the desirous reader and Eurydice that of the impenetrable work of art. Valastyán argues with Blanchot that the critical intention and hope conceived in the illusion of touching - coming into relation with the other - is doomed to be an ironic, hopeless gesture taken in the direction of the work of art. Eurydice can never be "saved" by Orpheus's look; she can never be reclaimed from the deep (Valastyán 1999). The sense of touching the other (as in the $5^{\text {th }}$ century Attic relief) is nothing but the illusion of touching (obtaining). The irony arises in/from the paradoxical gesture of the touch, being and meaning closeness and distance at the same time. The touch - as well as the look - are what unite and separate reader from work of art. One could say that the presence of the fragments of myths in Coetzee's novels might be seen as carrying such an Orphic critical-understanding function in his prose, trying to - through a self-reading, self-understanding gesture - bring meaning, embed and "tame" these painful narratives into (known) stories (through myths' "innate"-archaic "universalizing" nature), but given the private-unique event(-like) nature of these texts, the novels continually elude the rendering of such a "universal" meaning.

The Master of Petersburg evokes the myth of Orpheus (and those of Penelope and Daedalus) as underlying subtexts behind the story of the death of Dostoevsky's son and of his mourning. These myths are there in place of. As in Rilke's poem "Orpheus. Eurydice. Hermes.," in which it is not Orpheus who is crying but his lyre instead of him ("out of one lyre / more grief came than from all grieving women"), in this novel these myths bear a figurative logic and have a tropological function. Like Penelope, with these myths Dostoevsky weaves a new tapestry, composing his loss in different ways - into patterns. Coetzee's recourse to the fragments of mythological references in the novel carries a "tropological" function of "patterning" or "screening." These myth fragments function as metanarratives to the characters' stories of identity serving to complement their narratives precisely through their fragmentariness. 
The story may be interpreted as an allegory of Coetzee's use of myth, as well as an allegory portraying and entwining the many failed intersubjectivity plots of Coetzee's fiction. Blanchot's reading of the myth (2008, 60-61) helps in examining the two attitudes to intersubjectivity staged in it and in Coetzee's novels discussed here: Orpheus desiring but, at the same time, destroying the other and Eurydice declining the other's approach. Orpheus's and Eurydice's contrasting attitudes can be seen as manifestations of a failure of (in) love, one for its violence, the other for its neglect.

The Master of Petersburg deliberately and repeatedly calls the Orpheus legend into play, by having Dostoevsky refer to himself as a (failing) Orphic figure: "Poetry might bring back his son. [...] But he is not a poet. [... ] A gate has closed behind his son, a gate bound sevenfold with bands of iron. To open that gate is the labour laid upon him" (Coetzee 2004a, 17, 19). Mike Marais's (BlanchotianLevinasian) reading of the novel marks the presence of the Orpheus story in the novel as a myth that serves as a metaphor for the desire which inspires Dostoevsky to write (suggesting a relation between writing and death, Orpheus's encounter with Eurydice being an encounter with the dead) $(2006,90) .^{2}$ Just like Orpheus, Marais argues, Dostoevsky betrays (rather than reestablishes) the filial relation (2006, 91). The consequent paradox of the novel, Marais notes, is that in failing to find the right words in his mourning, he establishes what Levinas terms as “unrelating relation” (1969, 295, quoted in Marais 2006, 92).

According to the legend, Orpheus is driven into the underworld by his desire for his wife. So, unlike Perseus, Heracles, Theseus, or Iason, he undertakes the trip to Tartaros out of love; he goes down wailing (Kerényi 1977, 366). Even Hades is moved by his song and he only shows mercy once, allowing Orpheus to bring his wife back to the land of the living as long as she walks behind him and he never tries to look at her face until they reach the surface. Dostoevsky "thinks of Orpheus walking backwards step by step, whispering the dead woman's name, coaxing her out of the entrails of hell; of the wife in graveclothes with the blind, dead eyes following him, holding out limp hands before her like a sleepwalker" (Coetzee 2004a, 5). In the myth, Orpheus agrees but fails, looking back at the very end to make sure his wife is following, and thus he loses Eurydice forever (Graves 1981, 159). The novel conjures up the central moment of Orpheus's attempt to rescue his wife - the act of looking backward:

Not oblivion but the moment before oblivion, when I come panting up to you at the rim of the well and we look upon each other for a last time, knowing we are alive, sharing this one life, our only life. All that I am left to grasp for: the moment of that gaze, salutation and farewell in one, past all arguing, past

2 Chiara Lombardi (2010) also examines the myths of Orpheus and Eurydice and that of Eros and Psyche as illustrations and representations of the paradoxical relation between life and writing. 
all pleading: 'Hello, old friend. Goodbye, old friend.' Dry eyes. Tears turned to crystals.

I hold your head between my hands. I kiss your brow. I kiss your lips.

The rule: one look, one only; no glancing back. But I look back. [...] Forever I look back. Forever I am absorbed in your gaze. (Coetzee 2004a, 53-54) ${ }^{3}$

The test Hades sets on Orpheus is a test of desire. It is Orpheus's desire for the other, the beloved woman - not to resist looking backwards - that finally "kills" Eurydice;" it is the very desire for an encounter with the other that sends the other away. As Gillian Rose argues, Orpheus's "mistake” consists in gazing at Eurydice and thus risking everything $(1996,110) .{ }^{5}$ Blanchot reads Orpheus's backward look at Eurydice as transgressive precisely because of its violence in wanting to possess - and by possessing destroy - the (otherness of the) other:

Eurydice is the strangeness of the extreme distance that is autrui at the moment of face-to-face confrontation and when Orpheus looks back, ceasing to speak in order to see, his gaze reveals itself to be the violence that brings death, the dreadful blow. [...] man facing man like this has no choice but to speak or to kill. [...] should the self ever come under this command - speech or death - it will be because it is in the presence of autrui. $(2008,60)$

"Cain killing Abel," Blanchot goes on, "is the self that, coming up against the transcendence of autrui," attempts to confront it by resorting to murder (2008, 60). He adds, however, that in this alternative speech/murder, "speech is no less grave than death" $(2008,62)$. Orpheus descends into hell to bring back his beloved but he comes back alone. He was able to move and charm and delight anyone with his song, he even has Sisyphus sit down and rest on his boulder, making

3 Though primarily alluding to the Orpheus legend, the motif of looking backward is present in the Daedalus-Icarus legend as well, in relation to Daedalus the father, who looks back from his own flight to see how his son manages with his wings. Daedalus's look behind is the loving backward glance of the father at his son. The image of looking backwards at the same time invokes the biblical episode of a transgressive act of looking back: the story of Lot's wife. Looking back turns the looker into a salt pillar, indicating the frozen, arrested temporality of melancholia, the inability to mourn and thus work through the loss, illustrating the "unnatural," painful convulsiveness of the melancholic.

4 In Coetzee's novel, it is suggested that Dostoevsky is responsible for and implicated in Pavel's death. Allusions to his implicating himself in Pavel's death abound: "I will come back. The same promise he made when he took the boy to school for his first term. You will not be abandoned. And abandoned him" (Coetzee 2004a, 5). Ironically, the novel opens with his already late arrival to Petersburg; his son dead.

$5 \quad$ Like in Rilke's poem “Orpheus. Eurydice. Hermes." (1904), it is the undoing (failing to obey the prohibition and looking backward) which makes the work: "If only he might / turn once more (if looking back / were not the ruin of all his work, / that first had to be accomplished)" (Rilke/ Kline). 
even the stones (all that was wild [Kerényi 1977, 313]) enchanted by his song, but now, on encountering his real other/autrui in Eurydice, he is no longer able to move her, as this is most beautifully presented in Rilke's "Orpheus. Eurydice. Hermes.:" "the slim man" is "mute and impatient, gazing before him;" his hands "hung, clumsy and tight" [Rilke/Kline]). He so much awaits the encounter with his beloved that he is "no longer aware of the weightless lyre, grown into his left side." His desire for the other is so elementary he even forgets about his lyre concentrating all his strength and attention on the moment of encounter (Valastyán 1999). "His steps ate up the path in huge bites / without chewing: / [...] ran ahead like a dog, / turned back, came and went again and again, / and waited at the next turn" (Rilke/Kline). Never has a journey been so long, never has a look been waiting more eagerly for a return-look (Thomka quoted in Valastyán 1999). Orpheus turns back and this is the cause of their tragedy. Kerényi and Valastyán discuss a $5^{\text {th }}$-century Attic relief representing of the encounter of the three - Orpheus, Eurydice, and Hermes - which shows the woman holding the hand of both men, with a hand taking leave of her husband and being taken by the other hand by Hermes, who already escorts her back (Kerényi 1977, 268). Eurydice lays her hand on Orpheus's shoulder and he holds her hand - thus taking a last farewell from each other - and, at the same moment, Hermes too takes Eurydice's hand thus signaling his destination of escorting her back to the underworld. The uniqueness of this representation stands in that it so powerfully presents the tension of separation and connection (Valastyán 1999).

The power of Rilke's poem lies in its extremely sensitive concentration on, and presentation of, the figure of Eurydice. Unlike Orpheus, who is eager and impatient for the encounter, Eurydice - "the so-beloved" (Rilke/Kline) - is "uncertain, gentle, and without impatience. She was in herself, like a woman near term" (Rilke/Kline) or, in Stephen Mitchell's translation: "She was deep within herself, like a woman heavy / with child, and did not see the man in front / or the path ascending steeply into life" (Rilke/Mitchell). She is as if awaiting the event of the encounter - like a mother ("heavy") awaiting the miracle of birth - but she is in fact "deep within herself" (Rilke/Mitchell) she "did not think of the man" (Rilke/Kline). She is "without impatience. She was in herself" (Rilke/Kline). The encounter between the two of them does not take place; it is impossible to take place as Eurydice is alone, deep in herself, declining Orpheus; she does not want to because she cannot encounter the other. She cannot turn (her looks) to the other, because she turns (in)to herself. She no longer desires the other, the other's intimacy ails her: "She was no longer that, that man's possession no longer" (Rilke/Kline).

Orpheus's and Eurydice's reactions might be seen as allegories of Coetzee's portrayals/representations of intersubjectivity. Orpheus desires the other (and with his desire kills her), while Eurydice declines intersubjectivity. Coetzee 
seems to change the gender roles: in his novels, it is the female characters Magda, Susan Barton - who represent the impatient Orphean/Orphic desire for an encounter with the other, while male characters such as Friday or Michael K represent the Eurydicean closure or inability (or resistance) to an encounter with the other. They (Michael K as well as Friday or the barbarian girl, occasionally) personify Eurydice's question from Rilke's poem - "Who?" - not even realizing there is another there, incarnating loneliness; they are like Eurydice, the lonesome ones closed into themselves. They are at the same time Orpheus/"orphanos" (from the Greek and Latin word), fatherless, orphan (the name Orpheus originates from the Proto-Indo-European verb root "orbh," meaning to put asunder, apart, to separate) (Freiert 1991, 46). Orpheus's and Eurydice's contrasting behaviors might be seen as failures of love, of "love turned inside out" (Coetzee 2004a, 125), one through excess and violence, the other through indifference.

Indeed, Waiting for the Barbarians as well as Life \& Times of Michael K seem to tell the (colonial) story (of intersubjectivity) that the full stops (the punctuation marks) act out and stand for between Orpheus, Eurydice (and Hermes) in the title of Rilke's poem: "Orpheus. Eurydice. Hermes." Instead of using a comma between the names, the full stops suggest an unbreakable barrier between the protagonists. Orpheus and Eurydice's myth thus tells the story of an encounter in which one can only come close to the other but never close enough. Eurydice comes from a different world (she's dead) - she is other - and she will remain in this different world; she comes only to depart. The penetrating-aggressive Orphic gesture the (possessing) look - has no effect on Eurydice who remains unchanged and untouched by the encounter with Orpheus. Her question "Who?" in Rilke's poem is more tragic than the Magistrate and the barbarian girl's "goodbye," which at least acknowledges the presence of the other (even if acknowledging the impossibility of union/encounter). Eurydice does not even realize there is another there (that Orpheus was there). Orpheus remains a mere spectator like in another sonnet of Rilke's: "And we, spectators always, everywhere, / looking at [...] we live our lives, forever taking leave" ("Eighth Sonnet”). Orpheus takes leave in Rilke's poem(s), Eurydice does not even do that. "Who's turned us round like this, so that we always, / do what we may, retain the attitude / of someone who's departing?" Rilke's poem suggests an innate "separateness" (challenging the Platonic myth). In Rilke's "Orpheus. Eurydice. Hermes." both Orpheus and Eurydice depart, but while Orpheus departs from Eurydice, Eurydice departs from noone. While Orpheus is changed by/after the (non)encounter - he stands there "someone or other, whose features / were unrecognizable," nothing happens to Eurydice, who walks backward as she came "by that same path," "uncertain, gentle, and without impatience" as she was before. The encounter cannot take place, not even through the mediation of a third party - Hermes, who is present between the two of them as a messenger, to mediate between the two but whose physical presence reminds 
of the impossibility of an unmediated ("naked") union between the two of them. Hermes is there instead of Hades (replacing Hades), who, as if he already knew, his forbidding word to Orpheus a (paternal) warning to him, like an index finger, "take care," "mind you," the forbidding word without which there is no desire, that sets desire on and the godly gesture that makes Orpheus (as a desiring being) be born.

The function of the fragments of myths in the novels discussed would be, then, to embed the unbearable, terrifying encounter in some context that will render the forever wounded and wounding nature of the encounter meaningful. Their function would be something similar to the intermediary function of Hermes in the Orpheus-Eurydice encounter. The human relation is terrible, Blanchot says, because it is tempered by no intermediary $(2008,59)$. The myths, as evoked by Coetzee, might be said to have this "Hermes-like" intermediary function: to alleviate and temper the terrible-traumatic (metaphysical and colonial) encounter in Coetzee's fiction. His recourse to these mythological references suggests possibilities of rewriting the myths, but in very fragmentary and erratic fashion: myths are present as momentary flashes, and it is precisely their momentariness that makes their presence so meaningful in Coetzee's oeuvre.

The mythical fragments and flashes (often not longer than half a sentence) are themselves like the ever-elusive, traumatic nature of the event of encounter in Levinas. They flash up only to disappear in the next moment, in the next sentence. The singularity of the encounter, its traumatic "eventness," unsuited to the stability, continuity and durability usually attributed to myth, takes away the comforting meaningfulness and coherence of myth, perhaps reawakening the forgotten traumatic core of the encounter with the (divine, human) other that gave rise to mythological stories in the first place. In Coetzee, myths flash up for a painful instant (as if) repeating the unembeddable nature of the encounter.

\section{Works Cited}

Blanchot, Maurice. 2008. The Infinite Conversation. Trans. Susan Hanson. Minneapolis and London: U of Minnesota P.

J. M. Coetzee. 1986. Foe. New York: Penguin.

J. M. Coetzee. 1998. Life \& Times of Michael K. London: Vintage.

J. M. Coetzee. 1999. In the Heart of the Country. London: Vintage.

J. M. Coetzee. 2004a. The Master of Petersburg. London: Secker \& Warburg.

J. M. Coetzee. 2004b. Waiting for the Barbarians. London: Vintage.

Freiert, William K., Dora Carlisky Pozzi, and John M Wickersham, eds. 1991.

Myth and the Polis. Cornell: Cornell UP.

Graves, Robert. 1981. A görög mítoszok. [The Greek Myths.] Budapest: Európa. Kerényi, Károly. 1977. Görög mitológia. [Greek Mythology.] Budapest: Gondolat. 
Kerényi, Károly. "Hermész, a lélekvezető. ["Hermes, the Soul Guide."] http://filozofia-miskolc.net/wp-content/uploads/2011/11/Kerenyi1Hermes. $p d f$ (Last accessed 10 February 2016)

Kulcsár Szabó Ernő. 1991. "Mérték és hangzás (Az orfikus tárgyiasság Rilke kései lírájában)." ["Measure and Sounding (Orphic Objectivity in Rilke’s Late Poetry).”] Orpheus 2-3: 152-169.

Levinas, Emmanuel. 1969. Totality and Infinity. An Essay on Exteriority. Trans. Alphonso Lingis. Pittsburgh: Duquesne UP.

Lombardi, Chiara. 2010. "Under the Gaze of Orpheus. J. M. Coetzee and the Writing of Disaster."' Interférences Littéraires. no. 4. May. http:// interferenceslitteraires.be/sites/drupal.arts.kuleuven.be.interferences/files/ il4chiarralombardi.pdf (Last accessed 10 February 2016)

Marais, Mike (Michael). 2006. Death and the Space of the Response to the Other in J. M. Coetzee's The Master of Petersburg. In J. M. Coetzee and the Idea of the Public Intellectual, ed. Jane Poyner, 83-99. Athens: Ohio UP.

Rilke, Rainer Maria. 2005. "Eighth Sonnet." Duino Elegies and the Sonnets to Orpheus. Trans. A. Poulin. New York: Mariner Books.

Rilke, Rainer Maria. "Orpheus. Eurydice. Hermes.” Trans. A. S. Kline. http:// www.poetryintranslation.Com/PITBR/German/MoreRilke.htm\#anchor_ Toc527606964 (Last accessed 10 February 2016)

Rilke, Rainer Maria. “Orpheus. Eurydice. Hermes.” Trans. Stephen Mitchell. http://www.memory-fish.com/burt/poetry/misc/rilke.html (Last accessed 10 February 2016)

Rose, Gillian. 1996. Mourning Becomes the Law. Cambridge: Cambridge UP.

Valastyán Tamás. 1999. "Hermész, Eurüdiké és Orpheusz. ["Hermes, Eurydice and Orpheus.”] Gond. Filozófiai esszéfolyóirat no. 18-19. http://www.c3.hu/ gond/ tartalom/18-19/fravalasty.html (Last accessed 10 February 2016) 